\title{
Den lange vej til arabisk demokrati
}

\section{Erik Boel}

Om de reformer, der er sket i flere arabiske lande, vil blive omsat i en mere dybtgående politisk omstilling, afhænger af, om reformpolitikerne kan udvikle en attraktiv social dagsorden som supplement til deres mere abstrakte politiske krav

"Det er USA's politik at støtte fremvæksten af demokratiske bevægelser og institutioner i alle lande og kulturer med det ultimative mål at gøre en ende på tyranni i verden”. Sådan udtalte præsident Bush i sin indsættelsestale i januar 2005. Tidligere var stabilitet hjørnestenen i USA's erklærede mellemøstpolitik, i dag er det demokrati og frihed.

Terrorangrebene i Egypten har på ny aktualiseret spørgsmålet om demokratisering i Mellemøsten. Uanset megen retorik, mange donorpenge og arabisk selvransagelse efter 11. september er det fortsat således, at i Mellemøsten er Israel det eneste land, hvor borgerne kan slippe af med magthaverne gennem frie valg. Alle 22 medlemslande i den Arabiske Liga har i større eller min- dre grad autoritære regimer.

Udsigten til at der på kortere sigt bliver rettet op på tingenes skæve gang er ikke opmuntrende: De arabiske landes regeringer siger ganske vist alt det, vi gerne vil høre - men det skorter på den reelle vilje til i praksis at gennemføre demokratiske tilstande med alt, hvad det indebærer af uafhængige domstole, åbenhed i beslutningsprocessen, anerkendelse af grundlæggende frihedsog borgerrettigheder, et blomstrende civilsamfund mv. Måske foretager regeringerne en vis politisk liberalisering, men ikke reformer der kunne betyde, at de mister grebet om magten.

Den saudiarabiske regering har henvist til, at hvis den engagerer sig for stærkt i en reformpolitik, risike- 
rer den at støde de religiøse ledere fra sig, som den har hårdt brug for $\mathrm{i}$ kampen mod terror. De arabiske landes regeringer ved, hvor følsom især USA er, når det gælder kampen mod terror, og de bruger den som påskud til at retfærdiggøre krænkelser af menneskerettighederne. Men den velbegrundede dagsorden om bekæmpelse af terror må ikke skygge for eller ske på bekostning af vort ønske om fremme af demokratiet

På den anden side prioriterer de vestlige landes regeringer $\mathrm{i} \not \boldsymbol{~} ø \mathrm{j}$ grad forsyningsmæssige (læs: olie-) interesser og geostrategiske hensyn, når det kommer til stykket. Derfor har Vesten svært ved at formulere en konsistent dagsorden. Og på grund af først og fremmest Irak-krigen og Palæstina-konflikten kan de vestlige landes, og især USA's, troværdighed ligge på et lille sted.

Også i den offentlige opinion den såkaldte arabiske gade - er der tvivlrådighed: Mange spørger, hvor USA's pludselige interesse for demokrati i deres del af verden kommer fra. Det er et selvstændigt problem, at demokrati i Mellemøsten opfattes som en amerikansk ide.

Hvordan ligger det med en moderat reformorienteret opposition i de arabiske lande, som burde være vore allierede i indsatsen for demokrati? Her kan det konstateres, at med enkelte undtagelser er oppositionens demokratiske troværdighed af mere eller mindre tvivlsom karat.

Tidligere på året talte mange om “det arabiske forår”. Baggrunden var valget i Irak i januar, det palæstinensiske præsidentvalg, udviklingen i Libanon og tendenser i Egypten, der blev tolket som skridt på vejen mod mere demokrati. Men gassen er for længst gået af dén ballon, og stort set ingen taler længere om, at krigen mod Irak skulle have resulteret i en demokratisk dominoeffekt.

Volden i Irak er fortsat udbredt, og befolkningen deler sig i stigende grad efter etniske skillelinjer. I de palæstinensiske områder deltog Barghouti beklageligvis ikke i valgene. Han er kendt som en "hardliner", men det er ofte netop dem, der kan levere de politiske resultater, hvilket det kniber med for den nuværende palæstinensiske leder Abbas. I Libanon er Syrien ganske vist rykket ud militært, men trækker fortsat i de politiske tråde, og i det politiske liv er der ikke meget tegn på opblødning i Libanon. I Egypten tyder bl.a. behandlingen af den ledende oppositionspolitiker, Ayman Nour, ikke på, at præsident Mubarak har en reel vilje til at indføre mere demokratiske tilstande.

\section{Demokrati på dagsordenen}

Men det er trods alt en kendsgerning, at fra Marrakesh til Cairo og fra Ramallah til Riyadh diskuterer og reflekterer araberne som aldrig før over indretningen af deres egne samfund. Demokrati er sat på den regionale dagsorden, bl.a. i den Ara- 
biske Liga. Emner der tidligere var tabu - som indførelse af en maksimal periode for valg af de politiske ledere - drøftes nu åbent, og spørgsmålet er ikke længere, hvorvidt reformer er påkrævet, men snarere hvilke, der er nødvendige. FN har påpeget, at Mellemøsten både er den mindst demokratiske region i verden, og samtidig den region, hvor ønsket om demokrati er stærkest.

Samtidig er araberne og Mellem$ø$ stlandene under pres. Den enkeltes identitet udfordres som følge af globaliseringen og informationsteknologien. Den økonomiske globalisering giver øget afhængighed og større sociale forskelle, og den svækker samtidig staternes rolle. Endvidere står landene over for en kæmpe udfordring, når det gælder demografien, jf. at befolkningerne vil blive fordoblet frem til 2050, og at $36 \%$ af araberne allerede i dag er under 15 år (i EU er det 16\%). Ud over 11. september og amerikanske krav om reformer, har socioøkonomiske og politiske forandringer op gennem 1980'erne og 1990'erne forstærket behovet for reformer.

Baggrunden for reforminteressen er også, at gamle ideologier som panarabisme og arabisk socialisme nok fortsat dyrkes af mange intellektuelle, men har mistet deres tiltrækningskraft i den brede befolkning og ikke har samme status som tidligere. Samtidig gør statistikken også indtryk: Den arabiske verden halter politisk, økonomisk, intellektuelt $\mathrm{og}$ forskningsmæssigt bagefter så at sige alle andre regioner i verden.

Efter et studieophold her i sommer i Washington står det klart for mig, at USA - siden demokratiprojektet blev lanceret efter 11. september 2001 - er blevet en del illusioner fattigere. Men amerikanerne har indhøstet vigtige erfaringer, når det gælder denne målsætning, som USA med rette har placeret øverst på den internationale dagsorden. Erfaringer, som også kan være nyttige i forhold til de bestræbelser, vi gør os fra dansk side, hvor vi har afsat 100 mio kr. årligt til at stimulere demokratisering under overskriften "det arabiske initiativ". Det hører med i billedet, at USA i dag er en Mellemøstmagt, ikke alene militært, men i høj grad også politisk og økonomisk. Lige så kontroversiel USA's rolle er, lige så central er den. Der kan derfor være god grund til at se nærmere på nogle af de erfaringer, man har registreret i forskningsmiljøet i Washington.

Først og fremmest står det i dag klart, at indførelse af demokratiske tilstande i Mellemøsten vil tage tid, lang tid. Og vi må være forberedte på tilbageslag i processen. Vi må også erkende, at der er grænser for hvad vi i Vesten - selv USA - kan udrette. Indsatsen for demokratisering af Mellemøsten bliver et langt, sejt træk. Det kan give bagslag, når ikke mindst amerikanske politikere giver 
indtryk af, at demokrati kan indføres med et knips med fingeren, og derved skaber urealistiske forventninger. Hvis der er et voldsomt pres for at opnå hurtige og synlige resultater, er der risiko for, at de relevante aktører, i Danmark Danida, griber ud efter de lavest hængende frugter og fx koncentrerer sig om at organisere konferencer og efteruddannelsesprogrammer i stedet for at gå ind i de mere følsomme spørgsmål om fordelingen af den politiske magt.

Det er naivt at tro, at indførelse af demokrati i de arabiske lande vil betyde enden på terrorisme. Men en arbejdsgruppe ledet af bl.a. tidligere udenrigsminister Madeleine K. Albright fastslår i en rapport fra juni, at "mere åbne politiske miljøer sandsynligvis vil svække de ekstremistiske ideologier, som nærer volden".

Vi bør se i øjnene, at ikke to lande i Mellemøsten er ens, når det gælder betingelserne for fremme af demokrati. Hvad der virker fornuftigt i et land, behøver ikke virke fornuftigt i et andet. Det er derfor nødvendigt at udvikle landestrategier.

\section{Den kulturelle dimension}

Dialogen med de arabiske landes regeringer er som antydet ikke altid lige nem. På den anden side er der ingen vej udenom. Selv når det gælder samarbejdet med private organisationer, som fx kvindegrupper, er vi afhængige af de pågældende rege- ringers direkte eller indirekte accept. Vi skal passe på ikke at pådutte dem projekter, som de kun accepterer, fordi de er presset til det. Vi bør være klare og kontante, når det gælder mål om åbenhed, retssikkerhed, folkelig deltagelse, ligestilling osv., men bør i højere grad overlade midlerne til gennemførelse af disse mål til de arabiske regeringer. De kender bedst selv deres egne lande, og står vestlige lande for projekterne risikerer vi også nemt at blive syndebuk, hvis de slår fejl.

Problematikken har en vigtig kulturel dimension. Det er ikke kun de arabiske regeringer, der frygter demokratiet, fordi de ser for sig, at det vil give kaos (dvs: true deres egne magtpositioner), det er også en udbredt folkelig følelse, jf. et arabisk ordsprog der siger, at 1000 års tyranni er bedre end ét års kaos. Lederen af Middle East Institute i Washington Edward Walker udtrykker det derhen, at mange arabere føler, at unødig hast i demokratiseringen kan fremme radikale kræfter og give ustabilitet.

Denne frygt for forandringer kender vi jo også fra vor egen del af verden. Men i Mellemøsten er baggrunden islamiseringen og en angst for, at sociale bånd går i opløsning og usikkerhed over, hvad der måtte komme i stedet. Bekymringen kan formentlig reduceres ved, at også Vesten bidrager til den økonomiske og sociale fremgang, der kan give håb om en bedre fremtid. 
De vestlige lande bør, om ikke gøre op med, så i hvert fald forholde sig mere udtrykkeligt til vore egne dobbelte standarder. I USA peger forskere på, at havde fx Saudi-Arabien gennemført et valg som Irans nylige præsidentvalg, ville USA have udråbt det som en kæmpemæssig triumf for demokratiets fremmarch i Mellemøsten. Selv om mange kandidater blev udelukket fra at stille op, var udbuddet af kandidater alligevel rimeligt repræsentativt for de politiske hovedstrømninger i dagens Iran. Men fordi USA har en sikkerhedspolitisk dagsorden i forhold til Iran, stiller det her særligt skrappe krav. I virkeligheden er det i dag kun i forhold til Iran og Syrien, at USA for alvor har skruet bissen på, når det gælder fremme af demokratiet.

Mange arabere kritiserer, at USA har ophævet sanktionerne mod Libyen, der har et notorisk repressivt regime. Vist intervenerer USA til fordel for Nour i Egypten, men når 3 saudiarabiske reformpolitikere får fængselsdomme fra 6 til 9 år for at kræve indførelse af et konstitutionelt monarki, reagerer USA ikke, ej heller når Jordan eller Bahrain slår ned på dissidenter. Når styret i Yemen massakrerer shiitere i den nordlige del af landet, siger Vesten ikke et kvæk. Manglende konsistens i de vestlige landes linje fremmer den arabiske kynisme, når det gælder Vestens virkelige motiver for at fremme demokratiet.

Det er vigtigt at se i øjnene, at der selvfølgelig på kort sigt er risiko for øget ustabilitet, når vi forsøger at fremme mere demokratiske tilstande i de arabiske lande. Men faren ved at lade stå til, er uendelig meget større.

Vi skal passe på med ikke at oversælge fordelene ved en demokratisering af Mellemøsten. Vi bør acceptere, at demokratiske regeringer ikke altid vil være positivt stemte over for de vestlige lande eller vore mål. Tænk på, at det tværtimod var et autoritært land som Jordan, der i sin tid var med til at indgå en fredsaftale med Israel. Nogle af de ledende oppositionspolitikere i dagens Syrien angriber deres regering for at ville genoptage fredsforhandlingerne med Israel. Det er muligt, endog sandsynligt, at demokratisering vil give islamistiske kræfter vind i sejlene. Det illustrerer, at Vestens interesser i sikkerhed og demokrati ikke altid falder helt sammen i forhold til Mellemøsten. I hvert fald ikke på kort sigt - og det er det korte sigt, der er afgørende i den politiske beslutningsproces.

Det kan konstateres, at reelt uafhængige, frivillige organisationer NGO'ere - er en udpræget mangelvare i Mellemøsten. Min egen erfaring er, at den typiske arabiske græsrod tidligere har været ambassadør og fortsat har særdeles tætte kontakter i regeringsapparatet, og at hans "NGO" er sponsoreret af præsidentens hustru! Mange taler ligefrem om "gongo'er": government-organized 
nongovernmental organisation. $\mathrm{Og}$ de græsrødder, der faktisk er uafhængige, ønsker ofte ikke at samarbejde med de vestlige landes regeringer, fordi det kunne kompromittere deres integritet. I sidste ende er det også et åbent spørgsmål, hvor megen folkelig mobilisering fx USA reelt ønsker, idet Washington frygter "den arabiske gade".

I forhold til dagsordenen for demokrati er det et selvstændigt problem, at de mange NGO'ere er særdeles fragmenterede og ikke har en fælles overordnet social og politisk vision. Et vigtigt skel går mellem islamisterne og de pro-demokratiske bevægelser, der tværtimod finder, at et liberalt samfund er det eneste bolværk imod islamisering.

\section{Den farlige forenkling}

Forskeren Amy Hawthorne har gjort opmærksom på, at vestlige demokratimagere ofte har en opfattelse af arabiske NGO'ere, der på samme tid er for bred og for smal: De har på den ene side ganske overdrevne forventninger om, at sådanne organisationer vil kunne danne en "modvægt" til de respektive regeringer. Men samtidig begrænser de sig på den anden side i samarbejdet til den type NGO'ere, de kender hjemmefra og er trygge ved. Det er NGO'ere, hvis ledere taler engelsk, og som føler sig hjemme i internationale cirkler.

Disse demokrati-aktivister kan være gode til at organisere konferencer, men har ikke større gennemslagskraft i forhold til "den arabiske gade", som tilhører islamisterne. Det er også symptomatisk, at når de arabiske regeringer føler sig truet, ser de truslen komme fra de bredt og folkeligt forankrede islamistiske organisationer og ikke fra de elitære demokratibevægelser, der støttes af USA og EU.

Forholdet til islamistiske organisationer i Mellemøsten er særdeles kontroversielt i USA. Sagen er forholdsvis enkel, når det gælder terrororganisationer som al-Qaeda eller organisationer, der forfølger deres dagsorden med fredelige midler, eksempelvis Det Muslimske Broderskab i bl.a Egypten. Vanskelighederne opstår først for alvor, når det gælder hybrid-organisationer som Hizbollah i Libanon og Hamas i de palæstinensiske områder. Det officielle USA har defineret dem som terrororganisationer.

Men Albright-rapporten peger på, at disse bevægelser dels udfylder væsentlige sociale funktioner, dels deltager i de lovlige politiske processer i deres respektive samfund. Forudsat at de nedlægger våbnene og også $\mathrm{i}$ praksis demonstrerer, at de er villige til at underlægge sig alle de demokratiske spilleregler, bør USA derfor efter Albrights mening ikke sætte sig imod, at disse grupperinger deltager i de politiske processer.

Mange i forskningsmiljøet i USA henviser til, at de islamistiske orga- 
nisationer er vitale politiske kræfter i regionen. For Marina Ottaway fra Carnegie Endowment er de slet og ret nøglen til opbygning af demokratier i de arabiske lande, og hun henviser til, at moderate islamistiske partier allerede deltager i de politiske processer i bl.a. Marokko, Algeriet og Jordan. Som et minimum bør vi lære dem at kende. Og selv om vi måske ikke finder grundlag for tættere kontakter med bevægelsernes ledere, bør vi ikke ignorere deres bagland.

Vi fremmer næppe heller mere moderate strømninger inden for disse grupperinger ved at vende dem ryggen. Det er også tænkeligt, at hvis de arabiske landes regeringer og vestlige lande indleder et samarbejde med mere moderate dele af disse bevægelser, vil det resultere i splittelse og opbrud, og i at de mere radikale elementer bliver skilt ud. Der kan ud fra et demokratisynspunkt være meget vundet ved, at de mere rabiate grupperinger på den måde bliver mere overskuelige $\mathrm{i}$ størrelse.

Albright peger også på, at for at forhindre at islamiske bevægelser så at sige kupper de politiske systemer, bør de arabiske forfatninger indføre mindretalsrettigheder, fx ved at indføre et overhus i landenes parlamenter der bl.a. har til opgave at beskytte sådanne rettigheder, eller ved at højesteret pålægges at sikre mod flertalsdiktatur.

For USA ligger der i de kommen- de år en stor opgave i at formulere en gennemtænkt politik i forhold til de islamistiske organisationer, der er fjendtligt indstillet over for Vesten og i hvert fald ambivalente, når det gælder forholdet til demokrati. Noget tilsvarende gælder vort forhold til de kritiske arabiske satellitkanaler som $\mathrm{fx}$ al-Jazeera.

En sådan selvransagelse er i endnu højere grad påkrævet i en europæisk - og en dansk! - sammenhæng, hvor opfattelsen af de islamistiske organisationer er aldeles unuanceret. Vi bliver også nødt til at forholde os langt mere aktivt til politisk islam, fordi de muslimske grupper i vore egne samfund ikke altid er lige velintegrerede.

\section{Flere succeskriterier}

Indførelse af flerpartivalg bør ikke være vort eneste succeskriterium. Groft sagt: hellere rettigheder end papvalg. Fremme af borgernes rettigheder vil konkret sige støtte til de demokratiske værdier og uafhængige domstole, et frit og uafhængigt civilsamfund, respekt for de grundlæggende menneskelige rettigheder osv. Kun på den måde kan vi sikre, at de nye demokratier bliver levedygtige, jf. at myndighederne i Sydafrika brugte lang tid på ordentligt at forberede de første frie valg efter afviklingen af apartheid. Gennemføres "frie valg" over hals og hoved som en showforestilling på baggrund af pres fra Vesten, der ønsker 
at demonstrere hurtige resultater, vil det kunne give bagslag.

$\varnothing$ konomisk støtte og professionel rådgivning til fremme af demokrati er kun en del af svaret. Irak-krigen er blevet et selvstændigt problem, som også skal håndteres. Krigen er af Washington blevet kædet tæt sammen med indsatsen for at fremme demokratiet i Mellemøsten. Så upopulær den krig er i store dele af regionen, er det ikke underligt, at den er blevet gift for bestræbelserne på at skabe en bredere forståelse for betydningen af at udbrede frihed og demokrati.

Krigen har ført til en styrkelse af radikale nationalister og islamister $\mathrm{i}$ de arabiske lande, og har generelt skabt en slags belejringstilstand, som gør det svært for regeringerne at slå ind på en reformkurs.

Indirekte har krigen måske fremmet reformiveren - om end på en ganske anden måde, end amerikanerne forudså: Udbredt vrede over krigen og de arabiske landes regeringers manglende evner til at forhindre den, har ført til stigende utilfredshed med status quo i store dele af Mellemøsten.

Som landet ligger i dag, er det afgørende, at vi - dvs. både USA og EU - helhjertet engagerer os i at få det svage demokrati i Irak til at fungere. I dag har vi en oplagt fælles interesse $i$ at fremme sikkerheden og demokratiet i Irak. Forvaltningen af den irakiske olie er her en vigtig test for de arabiske landes opfattelse af Vest- ens virkelige hensigter. Hvis USA forsøger at sætte sig på olien, og fx amerikanske virksomheder får alle kontrakterne, vil det bekræfte den værste arabiske mistanke om, at demokratiretorikken blot var et påskud.

Tilsvarende bør såvel USA som EU gøre en forstærket indsats for at få en fredsproces mellem Israel og Palæstina på skinnerne. Mange vil pege på, at reformer i de arabiske lande i sig selv vil gøre en løsning af Israel-Palæstina konflikten nemmere, jf. tesen om at to demokratier ikke går i krig imod hinanden. De vil også - med en vis ret - indvende, at de arabiske lande blot bruger denne konflikt og Irak-krigen som en dårlig undskyldning for ikke at reformere sig.

\section{Palæstina-konflikten}

Det er nærmest en nationalsport i mange af de arabiske lande at give andre skylden for de fortrædeligheder verden har påført dem - det være sig kolonifortiden, Israel, globaliseringen eller USA. Landene i regionen kommer aldrig videre med den indstilling - Det er nødvendigt, at de erkender, at problemerne kun bliver løst, hvis de arabiske lande selv tager hånd om dem.

Tilbage står, at en løsning af $\mathrm{Pa}-$ læstina-konflikten er vigtig i sig selv. Og en løsning vil også gøre det vanskeligere for de arabiske lande at bruge konflikten som påskud for at udsætte en demokratisering. 
Det er almindeligt at trække en parallel mellem bestræbelserne på at reformere Mellemøsten og anstrengelserne under den kolde krig med at nedbryde de kommunistiske diktaturer i Østeuropa. Også i Mellemøsten er der en vis, begrænset demokratisk tradition at bygge på fra 1930'erne til 1950'erne og igen i en periode fra midten af 1980'erne. Men parallellen holder ikke.

Mellemøsten i begyndelsen af det 21. århundrede adskiller sig markant fra Østeuropa under den kolde krig. I Østeuropa var oppositionsgrupperne i sin tid stærkere, de var demokratiske, og de så Vesten som forbillede. I Mellemøsten er oppositionen generelt svag, og den ser med stor skepsis på Vesten. Warszawa-pagtlandene var potentielle modstandere, mens de fleste lande i Mellemøsten er vigtige sikkerhedspolitiske og økonomiske partnere for Vesten.

I fx de baltiske lande var ønsket om national uafhængighed også en drivkraft for demokratiseringsprocessen, fordi såvel USA som EU stillede krav om en reel demokratisering som forudsætning for medlemskab af NATO og Unionen. Og mens det i de østeuropæiske lande var kommunismen, der var påduttet udefra, er det i de arabiske lande demokratiet, der betragtes med mistænksomhed og som et vestligt forsøg på at svække og undergrave disse lande. De liberale reformpolitikere betragtes ofte slet og ret som kollaboratører.
Ligheden ligger snarere i det negative. I Jugoslavien så vi i 1990'erne, hvorledes en række etniske og nationale konflikter førte til krige og konflikter, da låget så at sige blev taget af med centralregeringens fald. Hvis en række regeringer i Mellemøsten - fx i Jordan, Saudi-Arabien og Syrien - bliver væltet i de kommende år, vil vi opleve, at religiøse og etniske mindretal, der ofte går på tværs af statsgrænserne, vil insistere på deres rettigheder med voldelige sammenstød som det sandsynlige resultat.

Det er trods alt grobund for en behersket optimisme, når det gælder demokratiprojektets fremtid. For det første er medierne i de arabiske lande blevet langt mere kritiske - tag tv-stationenerne al-Jazeera og al-Arabiyya eller aviser som Cairo Times eller Saudi-Arabiens al-Watan. Selv om de arabiske landes regeringer ikke bryder sig om, hvad de ser og læser, er det ikke sandsynligt, at denne udvikling vil blive rullet tilbage.

\section{Israel som inspiration}

De unge i Mellemøsten er ved at blive en del af en globaliseret virkelighed med adgang til internet, satellittv mv. Under rejser i Mellemøsten har jeg gang på gang oplevet den fascinationskraft, Vesten - og især USA - øver på de unge. Det er naturligvis i høj grad vor økonomiske velstand, en friere seksualmoral, musik, film, mode osv., der trækker. Men 
jeg tror, at det stikker dybere, og at fascinationen også omfatter vore politiske institutioner og vore grundlæggende værdier. Om end mange arabere har vanskeligt ved at fatte, at vi samtidig støtter enevældige monarker og militærdiktatorer.

For det andet er der tale om eksempler, der smitter. Også i Mellemøsten følger de unge med i verden omkring dem. Under den såkaldte orange revolution i Ukraine kørte tvstationerne i fx Marokko nonstop reportager fra demonstrationerne i Kiev. På trods af historiske stereotyper gør udviklingen i Tyrkiet også indtryk. Tyrkiet gennemfører i disse år vidtrækkende demokratiske reformer - med en økonomisk vækst på omkring $10 \%$ og uden at sætte landets grundlæggende stabilitet over styr.

Paradoksalt nok er det for palæstinenserne måske Israel, der er den vigtigste inspiration, når det gælder demokratisering. De fleste palæstinensere er rygende uenige i den israelske regerings politik. Men mange af dem besøger jævnligt Israel, og det gør et stort indtryk, at befolkningen her kan komme af med deres politikere gennem frie valg. Samtidig slår det mange palæstinensere, at uanset Israels sekulære status, er der mulighed for at praktisere sin religion, som man måtte ønske det.

For det tredje er demokratiet i Mellemøsten nu for alvor sat på dagsordenen. Mange indvender, at demokratisering af Mellemøsten først og fremmest er et spørgsmål om retorik. Men i den internationale politik spiller retorik i sig selv en rolle - ikke mindst når den kommer fra den amerikanske præsident.

Det ny Irak blev ikke den ønskede katalysator for politisk liberalisering og demokrati i regionen. For mange amerikanere har det været en vigtig, ny erfaring, at det ikke rykkede i Mellemøsten som man forventede, og som det gjorde i sin tid i Østeuropa.

Alligevel har Irak trods alt i en vis forstand været med til at give et momentum for demokratiske forandringer. Krigen har skabt baggrund for selvransagelse i de arabiske lande og dermed været med til at sætte en dagsorden for demokrati. Efter at have forsøgt sig med forskellige begrundelser, af især sikkerhedspolitisk art, er det for USA i dag fremme af demokrati - altså en ideologisk målsætning - der er topprioriteten i Irak.

For det fjerde er den autoritære stat i de arabiske lande under pres teknologisk, bureaukratisk og moralsk. Selv i et land som Saudi-Arabien er der visse forsigtige eksperimenter med friere lokalvalg, og et vist civilsamfund med kvindegrupper og menneskerettighedsorganisationer er ved at vokse frem. Det er alt for lidt, og det går alt for langsomt - men tendensen til at disse grupper får større autonomi i forhold til staten er der trods alt.

Om reformerne vil blive omsat i en mere dybtgående politisk omstilling, afhænger bl.a. af, om det vil 
lykkes reformpolitikerne at udvikle en attraktiv social dagsorden til at supplere deres mere abstrakte politiske krav. Og af om det vil lykkes mere moderate islamister og sekulære oppositionsgrupper at danne en alliance.

I de vestlige landes fremtidige indsats for at stimulere demokratibestræbelser i Mellemøsten bør vi i højere grad bruge guleroden. Når EU har haft så stor succes med at fremme demokratiet i Østeuropa, hænger det i høj grad sammen med, at det var en forudsætning for, at disse lande kunne komme med i EU. Det tilbud har vi ikke til landene til Mellemøsten, men mindre bør også kunne gøre det.

Vi bør eksempelvis fra vestlig side tilbyde bistand og forbedrede handelsvilkår. Eller støtte de pågældende landes medlemskab af internationale organisationer, som fx WTO (Verdenshandelsorganisationen) og NATOs partnerskab for fred.

Men forudsætningen bør være, at disse lande gennemfører mere konkrete forbedringer, ikke alene i lovform, men også i den praktiske politik, fx en forstærket indsats mod tortur, flere politiske rettigheder til kvinder eller en ny valglov, der forbedrer mulighederne for folkelig deltagelse. De vestlige lande bør opfordre landene i Mellemøsten til hver især at udarbejde en køreplan for de politiske fremskridt, som kunne gøre det lettere for borgerne at stille deres ledere til ansvar.

\section{EU i Mellemøsten}

Meget taler for, at EU og USA i langt højere grad koordinerer vore bestræbelser, når det gælder demokrati i Mellemøsten. Om ikke andet så for at undgå, at de arabiske lande spiller os ud mod hinanden. EU's profil, når det gælder at forsvare muslimerne, er ganske vist ikke imponerende, jf. vor kolonifortid og mere aktuelt, hvorledes vi lod muslimerne i stikken i Bosnien og Darfur.

Men efter bl.a. overgrebene i Abu Ghraib og i Camp X-Ray på Guantanamo har europæerne, og ikke mindst de nordiske lande, som landet ligger i øjeblikket bedre forudsætninger for at fremme de menneskelige rettigheder i den arabiske verden. Omvendt har USA den vægt og indflydelse, der skal til for at gøre en forskel. For de arabiske regeringer gør EU ikke skade, men er heller ikke en central spiller som USA.

Men den amerikanske styrke kan være et tveægget sværd. Brugen af militær magt i fx Irak kan være med til at støde arabiske reformpolitikere fra USA. Og den markante profil og højstemte retorik kan også skabe farlige forventninger om, at det er muligt at opnå hurtige resultater i indsatsen for at inspirere demokratiske fremskridt.

På grund af den geografiske nærhed er det for Europa en nødvendighed at engagere sig i Mellemøsten. I EU oplever vi direkte politiske og økonomiske forandringer i 
Mellemøsten - tag fx immigrationsstrømmene. Gennem den såkaldte Barcelonaproces har EU gennem 10 år engageret sig i et økonomisk og kulturelt samarbejde med Middelhavslandene. Men i Europa går vi på tåspidserne, når det gælder de politiske reformer, hvor vi - altså EU overordnet set - i højere grad prioriterer fx kommercielle interesser. Når det gælder fremme af demokrati, er det siden 11. september amerikanerne, der har formået at sætte dagsordenen.

Først og sidst bør vi lære de arabiske lande bedre at kende - og de bør lære os bedre at kende. Både på ekspertniveau og i befolkningerne ved vi alt for lidt om hinanden. Fordommene er farlige, fordi de kan føre til stereotyper og had, der igen kan lede til vold og terror - og til restriktioner for rejser og immigration.

De vestlige lande bør i samarbejde med moderate arabiske lande i fællesskab formulere en politik for religiøs og kulturel tolerance. Vi bør sætte ind i forhold til undervisningen i skolerne, give bedre adgang til at lære arabisk og indføre udvekslingsordninger, bl.a. for studerende. Men en sådan politik vil kun blive kronet med held, hvis den også involverer civilsamfundene.

Her kunne vi lade os inspirere af "Next Stop Sovjet", hvor mange mennesker drog til Sovjetunionen i 1980'erne for at være med til at nedbryde fjendebilleder og fremme mellemfolkelige kontakter. På den måde vil vi kunne gøre den lange vej til det arabiske demokrati lidt kortere.

Erik Boel, tidligere chefrådgiver på Dansk Institut for Internationale Studier (DIIS), nu forstander på Krogerup Højskole 